\title{
USAGE OF DESIGN THINKING TACTICS AND IDEA GENERATION STRATEGIES IN A BRAINSTORMING SESSION
}

\author{
Naz A.G.Z. BÖREKÇI'
}

Received: 05.09.2014; Final Text: 09.03.2015

Keywords: Brainstorming, problem area, design thinking tactics, idea generation strategies, solution areas.

\section{INTRODUCTION}

A short-term educational project on corrugated cardboard shelf-ready packaging for baby food jars was carried out as part of an elective graduate course. The design project involved thirteen graduate students, who worked on the project for 18 hours spread across six weeks. The process began with a brainstorming session after the design brief was distributed. It was observed during the session that the participants used various tactics to initiate discussion in their rounds, displaying individual abilities to provide the session with input to which the other participants could respond. Besides, participants followed certain strategies for a continuous and cumulative discussion resulting in the determination of major solution areas. This motivated a search for answers to the following questions through an analysis of the documentation of the session:

- What were the tactics and strategies used by the participants?

- For which purposes and how were these tactics and strategies used?

- What were the reflections of these tactics and strategies on the discussions?

The aim of this paper is to provide insights into the individual and collective efforts in using tactics for generating discussions and strategies for generating ideas in design thinking. The paper begins with an overview of the design thinking literature on tactics and strategies. Following, the brainstorming technique used in the session, and the analysis procedure of the documentation are explained. The analysis of the documentation reveals the various tactics and strategies used by the participants. These are presented respectively in order to describe and illustrate their purpose and practice of use. The paper concludes with the presentation of a process model representing the design thinking taking place in the session, supported with tactics and strategies. 


\section{STRATEGIES AND TACTICS IN DESIGN THINKING}

Lawson (2000) explains that designers develop throughout their years of education and practice, a set of guiding principles that steer their approach to design problems. These principles are their personal views about how to practice design and are highly affected by experience. These principles acting as inner drives and the external constraints that are revealed in a design brief, are factors for the designer in determining his/her strategies in handling the problem. Lawson (2000) explains that designers are mostly able to determine their strategies after a quick scan of the design brief; the less detailed the design brief, the more comfortable designers are in determining their position in relation to the design problem.

Studies have shown that designers tend to be solution-oriented, adopting a working process that leads to the identification of solutions in an early phase of the design process, before the problem is fully understood (Lawson, 2000; Dorst and Cross, 2001; Cross, 2006; Lawson and Dorst, 2009; Wiltschnig, Christensen and Ball, 2013). This tendency of designers towards problem-solution co-evolution results in tentative design solutions that address critical issues about the problem, which Darke (1984) refers to as the primary generators. Cross (2006) explains this tendency as the urge of designers to treat design problems as ill-defined and so they formulate their cognitive strategies accordingly. The studies to which Cross refers indicate that designers approach design problems with an assumption that there are some conditions, goals or constraints that can be transformed. Thus, designers generate solutions that are appropriate to the problems as understood and then evaluate these solutions in accordance with this view. Early ideas may be singular or several from different perspectives, all worked on at the same time and requiring the designers to run parallel lines of thought (Lawson, 2000; Lawson and Dorst, 2009). Reflecting on such tangible features as form, these ideas are worked out in detail, may form basis for the development of new ideas and are sometimes combined or even replaced with more appropriate solutions later on in the process, hence providing a medium for the examination of the design problem in detail.

Lawson (2004) explains that, with their inherent design knowledge, designers can contribute to a design situation with what may not have been apparent in the problem as originally presented in the brief, but is later found to be relevant and of importance. This is a result of the fact that designers tend to be aware of the design possibilities that the problem area calls for (Lawson, 2004). Cross (1982; cited in Lawson and Dorst, 2009) remarks that the way in which designers approach a problem, affects the prior knowledge that they require, making a problem inherently subjective. Designers introduce their own constraints to the design problem based on domain knowledge and on the exploration of tentative solutions developed for the problems, as defined by the designers themselves (Cross, 2006).

Schön (1983; cited in Dorst, 2011) argues that designers, particularly those with experience, set frames for themselves that limit their view of the problem area, allowing them to bring their own approach to the problem. Once the core paradox of a problem is revealed to the designers through this frame and is dealt with, designers can then make a broader analysis of the problem to bring new frames for further exploration. Schön (1983; cited in Cross, 2006) considers problem framing to be a characteristic of reflective practice, during which designers name the features of the problem space to 
address and frame the particular areas of the solution space in which they decide to carry out their exploration.

Jones (1980) describes strategies as a list of actions determined by designers during the planning of a design process. Based on various methods, Jones classifies strategies according to the degree of preplanning, and the pattern of search. Lawson and Dorst (2009) consider strategies within the design process to be a type of thinking that can be broken down into three types: convention-based, situation-based and strategy-based. Strategybased thinking requires the designer to have sufficient knowledge of the design process to be able to foresee the actions required, but also to have the ability to interpret the available information in a design situation and integrate it into the process, making use of the consequences. This approach suggests that the designer has a personal way of dealing with a design problem and a commitment to the strategy that he/she has determined. An essential factor in strategy-based thinking is the ability of the designer to identify the central problem to the design situation, and then to bring his/her personal focus to understanding the problem and come up with appropriate solutions.

During studies carried out with three experienced designers, Cross (2006) made three specific observations. Firstly, the designers brought a systematic approach to the problem, exploring the system as a whole rather than being limited to the components directly related to the design problem. Secondly, the designers framed the design problem from their own distinctive and personal perspectives. Thirdly, they chose to bring a design solution from first principles, which Cross (2006) defines as the designers' effort to bring forms or structures that are appropriate to the identified requirements, based on the expected functions and aiming at creative designs.

Lawson (2000) explains design tactics as the ways in which designers, either consciously or unconsciously, control their thoughts towards creative and productive thinking within the design process. The actions that designers take in productive thinking involve looking at a problem from diverse perspectives and methods that bring people together for interactive discussions on a certain topic, such as brainstorming, rely on diverse points-of-view for a productive session (Lawson, 2000).

Brainstorming sessions present an opportunity for the generation of ideas, which stimulates the generation of further ideas (Cross, 1995). Once an accumulation of ideas begins, further discussions, rather than inspiring new ideas, may see group members improving upon earlier suggestions (Cross, 1995), using techniques such as mutation and combination (Gause and Weinberg, 1989).

\section{THE STUDY}

\section{The Participants}

The 13 participants of the brainstorming session described in this paper were graduate students of the Department, and all had an industrial design background. Nine were in MSc programs and four were in the $\mathrm{PhD}$ program; eight were female and five were male; and ten were from Turkey and three were from the Netherlands. The session was conducted in English. 


\section{The Design Brief}

The brief read as follows: "Baby food products sold in jars come with a variety of contents and are small in size. Placing these products on shelves is time consuming and laborious for staff and it is also difficult to keep track of which types have sold out and need to be replaced. Consumers experience difficulties in finding the products they prefer from among the stacked packages. The design challenge is to develop corrugated cardboard shelf-ready packaging for baby food jars ( $125 \mathrm{~g}$ and $220 \mathrm{~g}$ ) that permits both easy arrangement on shelves by market staff and removal of jars in the preferred amount by consumers. The final design solutions should:

- Protect the products during transportation from factory to warehouse, and from storage to the market shelf;

- Present clearly the contents of the box and contribute to brand advertisement;

- Allow consumers to remove single jars from box, or purchase an entire box for home use; and

- Hold a minimum of four (2,010 g) and maximum of 12 jars (2,700 g)."

Shelf-ready packaging (SRP) is a type of packaging used for fast moving consumer goods that are distributed widely and consumed frequently. The SRP is built and filled with the product content at the factory, after which it is warehoused, transported, opened and set-up at the market shelf, where its contents are displayed. Ideally, SRP should require minimum effort and interaction from the market staff in setting up the packaging and removing empty ones, should facilitate the following of product flow and should permit easy removal of the product from the SRP by customers (Romanik, 2013). Typically, shelf-ready packaged baby food jars come in corrugated cardboard (CC) trays containing between six and twenty jars, bound in shrink wrap (Figure 1).

\section{Brainstorming as an Idea Generation Method}

Brainstorming is a method for the generation of several ideas within a short time, bringing together a non-hierarchical group of people from diverse backgrounds and with different skills to carry out discussions (Cross, 1995; Pahl and Beitz, 1995; Roozenburg and Eekels, 1995). The group is expected to exercise suspended judgment (Wright, 1998), meaning that criticisms of ideas spoken out are withheld during the discussion before making a decision about them. More focused solutions will be attained if the group members are informed of the problem statement, have background information about the problem area and have a knowledge of currently available solutions (Roozenburg and Eekels, 1995).

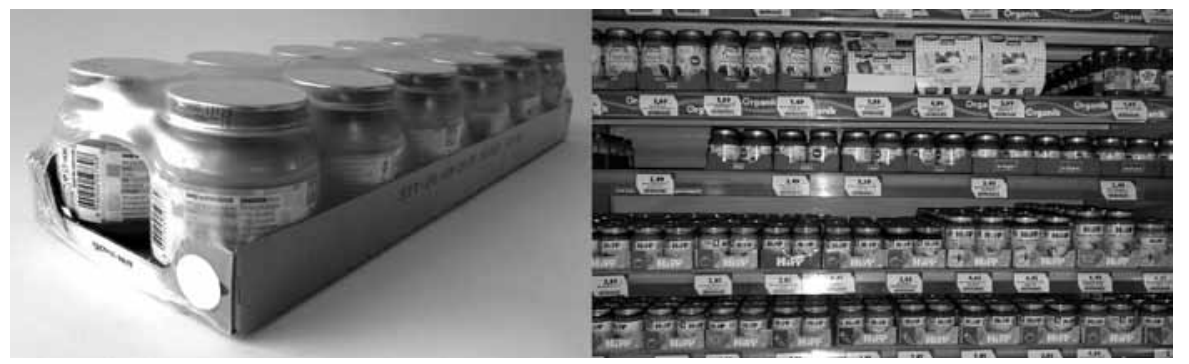


Figure 2. Left: A documentation sheet from Round 7. Right: A section of the tabulated documentation of the statements in Round 2.

A number of variants of brainstorming have been developed (Gause and Weinberg, 1989; Pahl and Beitz, 1995; Roozenburg and Eekels, 1995; Wright, 1998) with different recommendations regarding the ideal group size and the duration of sessions (Cross, 1995; Pahl and Beitz, 1995; Roozenburg and Eekels, 1995). There is general agreement, however, that the number should be enough to allow a fruitful session, but not so many that there are long intervals between the speaking turns of the individuals and repetitions of ideas. It is also deemed necessary to document the discussions and any generated ideas to allow their re-evaluation in the future. Ideally, at the end of the session some principal solution areas should have been identified (Cross, 1995), as well as one or two usable ideas (Pahl and Beitz, 1995).

\section{The Brainstorming Session}

The brainstorming technique used for the session adopted a variant of the Controlled Input Method (Wright, 1998), modified over time according to the educational purposes of the graduate course. The technique allowed each of the 13 participants to speak in turn, while the listening participants took notes of the discussions on sheets distributed for the session. The sheets included a table of three columns, titled "Summary", "Comments and Criticisms" and "Notes and Suggestions", providing a structured space for note-taking (Figure 2, Left). Five minutes were given to each round. When his/her turn came, the speaking participant had three minutes to think out loud and share his/her ideas on the problem area, after which, for two minutes the listening participants were allowed to speak and ask questions while continuing with their note-taking. Therefore, in the first part of each round, a speaking participant was expected to start discussions, and in the second part, the group had the opportunity to discuss altogether the issues brought up. A chronometer was used for timekeeping, and the session took 65 minutes in total.

\section{Analysis of the Outcomes}

At the end of the session, 156 sheets (13 rounds $x 12$ participants) were collected, containing the written statements and sketches of the participants. The statements of the note-taking participants, as well as the written descriptions of the sketches, were transferred to computer and listed according to each round, resulting in a detailed account of the input of each speaking participant in each round and the responses they elicited from the participants (Figure 2, Right). This document was subjected to content analysis, for thematically reviewing the discussion content.
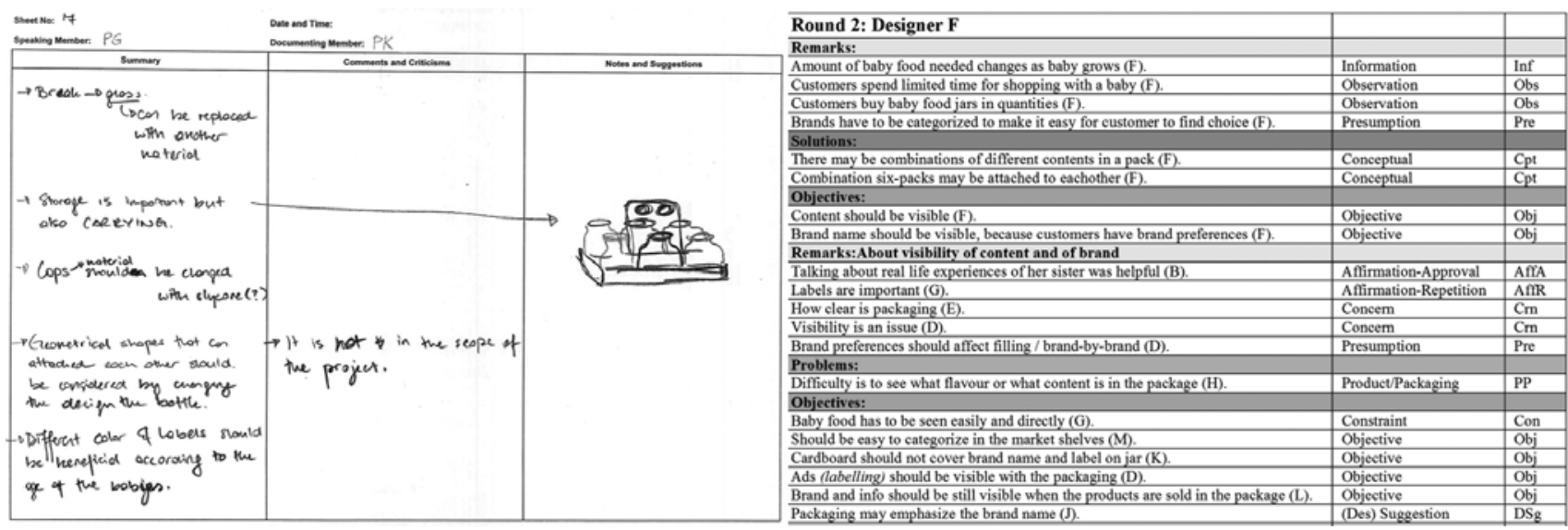


\section{DISCUSSION GENERATION WITH TACTICS}

As a result of the analysis, twelve design thinking tactics were identified, grouped under the three main tactic themes of involving personal experiences, solution-oriented analysis of the problem, and technical analysis of the brief. The tactics were used in generating discussions as each new round began. They were identified by the ways in which the participants brought up the discussion topics, responded to issues brought up in the discussions, presented their arguments, and made their design suggestions. The tactics were grouped according to their purpose of use and the skills involved (Table 1).

\section{Involving Personal Experiences}

The participants used past experiences in order to describe their involvement in similar contexts and their insights from these experiences. The participants gave accounts of observations on users and personal usages to illustrate the conditions under which they identified problems. They shared their experience on previously carried out relevant design projects. The participants made reviews of existing SRP examples and also used analogies to exemplify previously encountered design solutions or usage models.

Giving Accounts of Observations as Users

Speaking participant E in Round 1 used her past experience as a supermarket employee to provide the group with first-hand information on shelving considerations, describing the process of arranging products on shelves.

\section{Giving Accounts of Observations with Users}

Speaking participant $\mathrm{F}$ in Round 2 mentioned her experience with her sister, who was at the time the mother of a toddler. She described the problems that arise when feeding babies from jars during outings, the time limitations involved when shopping with a baby, and the difficulties faced when selecting food types from among many brand alternatives.

Making Use of Past Design Experience

Design Experience from Practice: Speaking participant $C$ in Round 3 shared his experiences from a project carried out in his second year undergraduate studio course about paper-based egg boxes. His focus was on the protection

\begin{tabular}{|c|c|}
\hline TACTIC THEMES & TACTIC CATEGORIES \\
\hline Involving Personal Experiences & $\begin{array}{l}\text { - Giving accounts of observations as users } \\
\text { - Giving accounts of observations with users } \\
\text { - Making use of past design experience } \\
\text { - Reviewing examples of SRP } \\
\text { - Using analogies }\end{array}$ \\
\hline $\begin{array}{l}\text { Solution-Oriented Analysis of } \\
\text { the Problem }\end{array}$ & $\begin{array}{l}\text { - Exploring the user } \\
\text { - Exploring the supermarket environment } \\
\text { - Exploring the home environment } \\
\text { - Reviewing peer ideas }\end{array}$ \\
\hline Technical Analysis of the Brief & $\begin{array}{l}\text { - Reviewing the project requirements } \\
\text { - Deviating from the design brief } \\
\text { - Providing technical information }\end{array}$ \\
\hline
\end{tabular}


of the jars, which, he suggested, could be provided by way of clever folding solutions in CC. Speaking participant J in Round 11 shared her experience from a project carried out in her first year undergraduate studio course on the packaging of porcelain cups and saucers. She was also concerned about the protection of the jars, searching for means to stabilize them in the packaging.

Design Experience from Project Supervision: Speaking participant K in Round 7 described her experience as a supervisor in a project on SRP for fast moving consumer goods, carried out in the fourth year undergraduate studio course. Her focus was on design considerations for CC packaging layout that is highly affected by manufacturing criteria.

Reviewing Examples of SRP

Speaking participant $\mathrm{E}$ in Round 1 described various shelf-ready packaging examples she came across during her work experience, in terms of how they were opened and set-up, how the product content was displayed, and how empty packaging was removed and discarded.

Using Analogies

Analogies Representing Design Solutions: Speaking participant $C$ in Round 3 used the analogy of an egg box to illustrate the usage of paper-based packaging for fragile items. He also used the analogy of plastic handles for six-pack mineral water bottles, suggesting that a similar solution could be utilized for baby food jars, serving both as a means for keeping the contents as a pack and for carrying. Speaking participant $J$ in Round 11 used the analogy of Lego to illustrate her idea of creating packaging that doubled as collectible toy pieces. Speaking participant I in Round 13 used the analogy of mobiles for babies, to suggest how packaging waste could be reused. He also used the analogy of a tray, to suggest a reuse possibility for the discarded cover of the packaging.

Analogies Representing Design Models: Speaking participant E in Round 1 used the analogy of shrink wrapped six-pack bottles to describe that it is easier to stack items on shelves in groups. She also used the analogy of an inclined box for toothpaste that she had handled at work to describe how jars could be displayed, and of vending machines to illustrate the idea of the jar above sliding down as the one below it is removed. Speaking participant $\mathrm{H}$ in Round 12 used the analogy of the FIFO (first-in-first-out) system to emphasize the idea that baby food jars should be consumed quickly.

\section{Solution-oriented Analysis of the Problem}

The participants were solution-oriented in their discussions and explored design solutions as a way of understanding the problem area. They decomposed the problem area into the dimensions of user, supermarket environment and home environment and discussed these dimensions while generating design solutions in response to issues brought up. As another tactic, the participants reviewed peers' design solutions by either approving the idea and adding onto it or criticising it and making alternative suggestions.

Exploring the User

Speaking participant E in Round 1 was the only participant who could provide insights from the point of view of the market staff. She explained the difficulties of stacking jars on shelves one by one and gave examples 
of packaging that could be refilled. Speaking participant M in Round 6 suggested that the nutritional needs and feeding habits of babies should be researched in order to understand how the product content of combomultipacks could be composed. Speaking participant $\mathrm{K}$ in Round 7 suggested that there should be handles for market staff and consumers to carry the pack considering the total weight. The weight of packs seemed to be a general concern. Speaking participant G in Round 8 mentioned that mothers with babies already have heavy bags with them and baby food jars with glass packaging would make them even heavier. This concern led the discussions towards reconsidering the structural properties of the packaging, the number of jars to take place in each pack and alternative materials for the jars to reduce the total weight. She also considered the visually impaired as a consumer group and suggested to add information in Braille on the jar labels.

Exploring the Supermarket Environment

Speaking participant $\mathrm{E}$ in Round 1 described the supermarket as a use environment and explained shelving considerations to the group. Her suggestion of inclined packs led the group discussions to explore how shelves could be made with an incline. Speaking participant $\mathrm{F}$ in Round 2 explained that her sister had difficulties in identifying her preferred brand and ingredient, describing how unorganised shelves can be. Speaking participant L in Round 9 reminded that it is also necessary to consider the stages of transportation and distribution of the multipacks. As there would be many jars from various brands, she suggested searching for means to avoid visual clutter on shelves. Speaking participant $\mathrm{H}$ in Round 12 returned to the idea of inclined shelves in order to encourage the consumption of the products that are shelved earlier, first.

Exploring the Home Environment

Speaking participant A in Round 5 mentioned the home as a use environment, suggesting to make research on how people store quantities of baby food jars at home, arguing that there may be limited space in the kitchen cabinets. She emphasized the importance of the stackability of packs on top of each other, for space saving and suggested that the packaging could be used as a means for storage in the home.

Reviewing Peer Ideas

Approving Peer Ideas: Indicating his approval of the ideas generated so far, speaking participant $\mathrm{D}$ in Round 4 generated further ideas for the problem of packaging waste. His approval had a positive influence on the following discussions, and from then on, participants generated design solutions that supported the initial ideas.

Criticising Peer Ideas: Speaking participant G in Round 8 stated that the packaging becomes heavier as it grows in size owing to the glass content, and suggested eliminating box-type CC packaging altogether. Speaking participant L in Round 9 objected to the idea of combo-multipacks and suggested instead that multipacks should contain one type of food only, so that the consumer does not have to purchase a pack that contains types of food that will not be consumed. Speaking participant B in Round 10 stated that excessive material is used for the box-type packaging and suggested searching for solutions that use less CC. 


\section{Technical Analysis of the Brief}

Another group of tactics involved the checking of the brief, with the purpose of keeping in line with the design problem as presented. The participants reviewed the project requirements particularly in situations where they felt that the discussions were not within the scope of the brief or that requirements were not being met. The participants also made design suggestions that contradicted the brief to explore the limits of the problem area. In order to supplement the discussions, the participants shared all available information that they believed would be critical for making design decisions.

Reviewing the Project Requirements

Speaking participants C in Round 3, L in Round 9 and J in Round 11 felt the need to review the project requirements with the group. Speaking participants $\mathrm{C}$ and $\mathrm{L}$ were concerned that the group had not considered one particular project requirement -that the SRP should allow the removal of a single jar from the packaging while on the shelf. Speaking participant $\mathrm{J}$ revised the project requirements in her round, which took place towards the end of the session, to make sure all was covered so far.

Deviating from the Design Brief

Extreme Deviation: The insights that speaking participant E provided in Round 1, led group discussions towards reconsidering the design of shelves as a solution to the design problem. The ideas that were generated in response were discarded by the group based on the argument that shelf design is not among the project requirements. Speaking participant $\mathrm{G}$ in Round 8 suggested changing the materials of the jar and cap so as to eliminate CC packaging altogether. Although the suggestion stimulated discussion, the group restated its determination to remain within the limits of the brief. Speaking participant $\mathrm{H}$ in Round 12 suggested using inclined shelves, but evolved this idea into a CC packaging with an inclined inner surface.

Supplementing Deviation: Speaking participant $C$ in Round 3 suggested using plastic holders to keep six jars attached. Although this implied no usage of CC packaging, the group developed this idea into design solutions made from CC that would hold jars from their necks. Speaking participant J in Round 11 was concerned that jars in a pack may rattle against each other during transportation and suggested that additional plastic pieces could be used to keep them separate. In response to her self-criticism on the usage of additional packaging material that would go to waste, she converted the plastic separators into collectible toy pieces. She evolved her own idea into a toy made out of the packaging and then into a packaging that could come as a toy without requiring modification. The ideas generated in the round found acceptance from the group, considering that the target consumer group is parents of young children and influenced the discussion topics covered in the following final two rounds.

Providing Technical Information

Doubtful of the suitability of the design solutions suggested so far for corrugated cardboard, speaking participant $C$ in Round 3 informed the group on the material properties of corrugated cardboard, based on his design experience. Speaking participant K in Round 7 informed the group on the manufacturing criteria related to CC packaging, again based on her design experience. Speaking participant L in Round 9 talked about 
the usage and lifecycle of CC shelf-ready packaging, according to her knowledge.

\section{Discussions on Tactic Usage}

The tactics were used for identifying discussion topics, starting the discussions, steering the discussions, branching the discussions, running parallel discussions thus ensuring continuous discussions towards idea generation. In order to enrich the discussions the participants aimed at diversifying the topics covered and for this they varied their tactics to be able to bring forth new issues regarding the problem area. It was seen that all participants used multiple design thinking tactics in their discussions. Experience in the problem area facilitated tactic variation. The usage of tactics was highly influenced from personal skills and experiences, which made tactic usage and variation an individual contribution to the session.

\section{STRATEGIES OF PARTICIPANTS}

As a result of the analysis, sixteen strategies were identified, grouped under the six main strategy themes of: combination multipacks, types of packaging, protection, visibility, display, and reuse. The strategies were followed for idea generation that took place in response to the issues raised in the discussions. The strategies were identified by the prioritized topics of discussion and by the variety of generated ideas. The strategies were grouped according to the idea content of the solutions (Table 2).

\section{Combination Multipacks}

The participants agreed in principle that the main design concept would be combination multipacks, or combo-multipacks, and searched for ways in which this could be done.

\section{Providing Ready Combo-Multipacks}

One strategy followed was to offer alternatives of ready combo-multipacks in the supermarket for consumers to choose from. Therefore, there would be various sealed packs of mixed ingredients. From this pack it would not be possible to remove a single jar of choice.

\section{Making Combination Multipacks}

As this seemed to be a limiting offer to the consumers, in another strategy it was suggested that the consumer could select the desired types of food in desired amounts and make their own combination packs in the supermarkets, using boxes provided on shelves. The ideas generated in accordance, involved either consumers picking jars one-by-one from a bigger pack, or, picking jars in groups by detaching or tearing off groups of jars from a connected packaging. The second strand of ideas searched for ways to attach these groups of jars that would already be packaged. Folding solutions were suggested to solve the "messy appearance" of the torn parts of the packaging remaining on shelf.

\section{Informing About How to Make Combinations}

In order to assist consumers in making combinations of food jars, it was suggested to offer on the packaging, tips and information for consumers on age-related nutritional needs, feeding schedules, and ingredients. These could be removed from the packaging to be collected or used as timetables. 
Table 2. Idea Generation Strategies Used in the Session.

\begin{tabular}{|c|c|}
\hline STRATEGY THEMES & STRATEGY CATEGORIES \\
\hline Combination Multipacks & $\begin{array}{l}\text { - Providing ready combo-multipacks } \\
\text { - Making combination multipacks } \\
\text { - Informing about how to make combinations }\end{array}$ \\
\hline Types of Packaging & $\begin{array}{l}\text { - Box-type packaging } \\
\text { - Other types of packaging }\end{array}$ \\
\hline Protection & $\begin{array}{l}\text { - Protecting content of box-type packaging } \\
\text { - Protecting content of other types of packaging }\end{array}$ \\
\hline Visibility & $\begin{array}{l}\text { - Using graphics on packaging } \\
\text { - Providing partial openings on packaging } \\
\text { - Open packs with shrink wrap }\end{array}$ \\
\hline Display & $\begin{array}{l}\text { - Displaying in stacked position } \\
\text { - Special arrangements of shelf } \\
\text { - Setting-up for display }\end{array}$ \\
\hline Reuse & $\begin{array}{l}\text { - Reusing waste parts of packaging } \\
\text { - Reusing whole packaging } \\
\text { - Reusing jars alone or in combination with } \\
\text { packaging waste }\end{array}$ \\
\hline
\end{tabular}

\section{Types of Packaging}

Corrugated cardboard to be used as the packaging material initially led the group to explore box-type packaging. As discussions continued, the rectangular box evolved into boxes of different shapes in one strand and open packages using lesser amounts of CC in the other.

Box-Type Packaging

The participants generated ideas on how a box-type packaging could be, how many jars it would contain, and how these jars would be placed within the box. A concern was to make durable boxes. Others were the layout design of the boxes to remain within CC sheet standards and to produce minimum production waste. Besides ideas for regular box-type packaging, towards the end of the session, various ideas were generated for boxes with irregular shapes, such as triangular, hexagonal, flower shaped, and cylindrical. Participants also explored the ways in which jars could be stacked in vertical and horizontal positions. This was done for brand distinction, for space-saving solutions on shelf, and for the placement of jars in odd numbers, such as seven jars for weekly packs.

\section{Other Types of Packaging}

Arguing that box-type packaging uses excessive CC material and is enclosed therefore prevents the jars to be seen, other means were explored to make open packs of jars. These were keeping jars together using CC straps, deep trays, slot trays, top covers, and layers of CC used on top or at the bottom of packs, all of which used CC together with shrink wrap.

\section{Protection}

A main concern was protecting the jars within the packaging and different strategies were followed for box-type and other types of packaging.

Protecting Content of Box-Type Packaging

The solutions included structural details for strengthening the packaging that would be stacked on top of each other during transportation and storage. The solutions also included flaps that could be folded out from the cover of a pack and inserted into the one on top. Another concern was 
preventing jars from rattling against each other during transportation. For this the suggestions included using plastic pieces to keep jars separate, using CC details for the same purpose, folding the cover of the packaging inwards to keep jars separate, and filling in the empty space between the top of the jars.

Protecting Content of Other Types of Packaging

In order to protect jars in packaging using shrink wrap, the main suggestions were to cover the top and bottom edges and to use CC corner bumpers.

\section{Visibility}

Brand distinction and ease of ingredient identification were found to be critical for marketing success.

\section{Using Graphics on Packaging}

It was suggested that graphics could be used on the surfaces of the combomultipack boxes to give information on the types of ingredients that the pack contains or indicate which meal of the day they are suggested for (breakfast, lunch and dinner).

\section{Providing Partial Openings on Packaging}

The solutions suggested openings on the side surfaces of the packaging, in order to allow the consumer to check the type of ingredient and make sure the jar is in good condition.

Open Packs with Shrink Wrap

Based on the argument that glass is already an expensive type of packaging and that it has aesthetic qualities referring to health, it was suggested to use a minimum amount of CC to display the jars while in the shrink wrapped pack. The ideas involved making use of the graphics on the jar labels together with the graphics on a CC printing surface provided on the packaging, for reflecting brand identity and presenting product information.

\section{Display}

Strategies were followed for suggesting the ways in which the packaging and its content would be displayed not only for marketing purposes, but also to provide ease for the market staff in arranging shelves and for the consumers in locating the desired products.

Displaying in Stacked Position

The participants searched for the possibilities of stacking more than two packs on top of each other, with an emphasis on the safe stackability of the packaging.

Special Arrangements on Shelf

The participants suggested ways for using graphics as a guide for shelving. With a label design that differs in colour according to the type of ingredient, it was suggested that a "harmony" could be provided in shelving arrangements, with the packs of jars forming gradual or repetitive patterns. 


\section{Setting-up for Display}

The participants also searched for means to display the jars in open. This required that the packaging would be opened and set-up at the shelf. In order to avoid waste that would have to be discarded, it was suggested to use the removed cover of the packaging, folded forward like a hanging flap, for presenting product-related information. Another strand of ideas explored the possibility of forming a fold-away handle on the cover, closing the pack again in the case of purchase, and using the handle to carry the pack. Others were providing an inclined display, for example by using an inclined inner surface with slots to place the jars. It was suggested that when the number of jars were reduced, an inclined packaging could be refilled from the back top side of the packaging, from where the horizontally placed jars could roll down to the front.

\section{Reuse}

Another concern was that packaging solutions are generally short-lived and as a strategy participants searched for means to extend the life of the packaging by suggesting reuse ideas. For all the ideas proposed following this group of strategies, it was suggested that the users could be guided with post-use ideas and instructions on the packaging.

Reusing Waste Parts of Packaging

The ideas suggested reusing the cover of the packaging that would be removed during set-up. In one strand, it was suggested to open and remove the cover diagonally and place it under the packaging to create an inclined display. In another strand, it was suggested for consumers to use the removed cover as a tray to collect jars of choice during shopping. Another group of ideas revolved around the possibility of reusing parts of the packaging as toy components and among the suggested ideas were making mobiles, Christmas tree decorations and collectible toy pieces out of packaging waste.

Reusing Whole Packaging

Considering that consumers would be making combination packs, it was suggested for empty packaging to be available on the shelves. These could be either flattened with a bellow, or collapsed. Considering that there would not be enough space in the kitchen for jars bought in quantities, it was suggested that the packaging could be reused as a storage unit in the home. Or else, the packaging could be reused as a personal "carrying tool" for shopping. Finally, it was suggested to offer packaging designs in the form of doll houses, which would be ready to play with when empty, without requiring modification.

Reusing Jars Alone or in Combination with Packaging Waste

A brief exploration was conducted for the post-use of the jars, such as making lamps out of them. It was also suggested that post-use possibilities could involve the usage of jars and CC packaging together.

\section{Discussions on Strategy Usage}

It was seen that the participants felt the need to enrich the design brief with additional considerations that they found in relevance to the problem area. Strategies were used for collectively shaping these considerations into project objectives during discussions and making sure that the group was in agreement with them. In the course of the discussions, these 
objectives turned out to be: marketing, for the commercial success of the product; sustainability, for displaying sensitivity to environmental issues regarding the life-cycle of the packaging; and user-product interaction, for a prolonged usage of the packaging. The strategies reflected the group's priorities in the search for solution areas, provided design directions to the discussions, explored the problem area from different perspectives and supported idea generation. Design interests and domain-related knowledge facilitated strategy variation for the participants. Variation of strategies led to the diversification and elaboration of the design ideas that concentrated around the objectives themes.

\section{CONCLUSION}

A brainstorming session was conducted with 13 designer participants following the issuing of the project brief, during which the participants explored the problem area, determined the main design concept and identified solution areas for which they generated design ideas. The documentation of the session was thematically analysed to identify the design thinking tactics and idea generation strategies that the participants used. As a result of the analysis, twelve design thinking tactics were identified that were used to generate discussions on a variety of topics for exploring the problem area in depth. The usage of tactics led to the early determination of the main design concept and the design solutions generated for this concept were explored together with the problem area throughout the session. Sixteen idea generation strategies were identified as a result of the analysis, which were used in collectively determining the project objectives and generating design solutions accordingly. The usage of strategies allowed a focused idea generation effort in terms of the project objectives.

The tactics and strategies were reviewed for the actions involved, in order to understand the motivation behind their use. By using tactics and strategies, the participants aimed to set the grounds for discussion by providing general background information, bringing explanations, giving examples and describing situations involving users and environments. The participants aimed at a more detailed idea generation by providing specific or technical information, finding precedents and searching for solutions in other areas. The participants aimed to extend the boundaries of the solution areas by approving or criticising design suggestions, making alternative suggestions and elaborating upon suggestions. The participants had a tendency for exploring and developing the design suggestions instead of criticising and eliminating, apart from those that deviated from the design brief (changing jar material; eliminating CC packaging altogether; redesigning the shelves to fit the packaging). The participants aimed at exploring the project requirements, by reminding of, warning about and seeking for agreement on the project objectives. Towards the end of the session (Round 10), the project brief was reviewed to make sure all requirements were covered, during which participants agreed that, due to lack of research on the problem area conducted prior to the brainstorming session, some requirements were not explored in depth. Therefore, tactic and strategy usage came into play also to compensate for the lack of information on the problem area.

Figure 3 represents the design thinking process taking place in the brainstorming session involving the usage of tactics and strategies. Following a solution-oriented approach, the participants generated design 


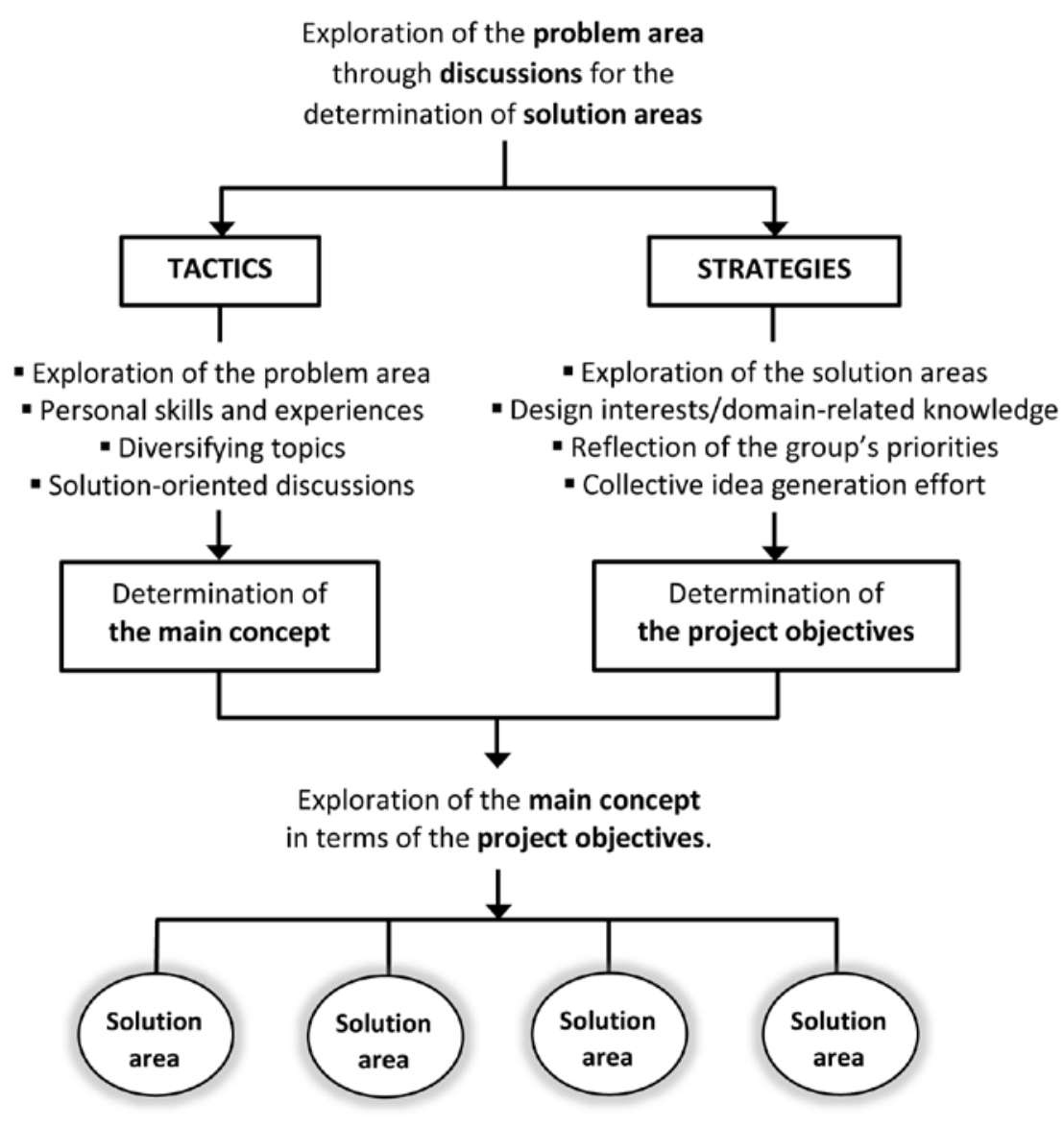

ideas starting from Round 1 and idea generation took place in all the rounds until the end of the session. The general tendency of the group was, determining a main design concept early in the session, decomposing the concept into its components and generating design ideas for each. The initial ideas were inspired from speaking participant E's work experience, followed by speaking participant $\mathrm{F}^{\prime}$ 's user experience, leading to the suggestion of the main design concept as "combination multipacks" made by the end of Round 2. From then on, this concept was taken as a basis for further discussions; participants used this concept as an early solution to the problem, exploring it together with the problem area, demonstrating the designers' tendency towards problem-solution co-evolution. During this exploration, discussions followed two approaches. In one approach, the main concept was decomposed into packaging components that were explored; the components were the cover, handle, base, side surfaces, inner surfaces, corners, edges, details, jar labels and packaging graphics. In the other approach, the main concept was explored in terms of the three project objectives of marketing, sustainability and user-product interaction. Exploration of the main concept from the perspectives of the project objectives facilitated thinking in parallel planes, and idea generation for more than one solution area was carried out in parallel throughout the session. It was thus possible to follow the evolution of the initial box-type CC packaging solution suggested for the main design concept into various other types of packaging solutions, such as those with irregular shapes and 
as others suggesting open packs using lesser amount of CC together with shrink wrap.

Overall, the brainstorming session was successful in supporting an exploration of the problem area. The technique used for the session required an organisation of thoughts and of the ways in which they were expressed. Another benefit was the systematic documentation that was carried out by all the participants, which resulted in an extensive documentation of the contributions of each speaking participant and of the evaluation of these contributions from the perspectives of each participant in the group. The analysis of this documentation provided both a rich source of idea content, and the possibility of following the design thinking taking place in the discussions. It is possible to record the ideas collectively generated for a design problem using other techniques. However, in order to evaluate the benefits of interactive discussions, it is important to find a technique that also makes it possible to identify the flow of thinking and the ways in which the ideas evolve within the group dynamics.

\section{BIBLIOGRAPHY}

CROSS, N. (1995) Engineering Design Methods: Strategies for Product Design, (2nd Ed.) John Wiley \& Sons, Chichester.

CROSS, N. (2006) Designerly Ways of Knowing, Springer-Verlag Limited, London.

DARKE, J. (1984) The Primary Generator and the Design Process, Developments in Design Methodology, ed. N. Cross, John Wiley \& Sons, Chichester; 175-88.

DORST, K. (2011) The core of 'design thinking' and its application, Design Studies, 32(6) 521-32.

DORST, C.H., CROSS, N. (2001) Creativity in the design process: coevolution of the problem-solution, Design Studies, 22(5) 425-37.

GAUSE, D.C., WEINBERG, G.M. (1989) Exploring Requirements: Quality before Design, Dorset House Publishing, New York.

JONES, J.C. (1980) Design Methods: Seeds of Human Futures (1980 Ed.) John Wiley \& Sons, Chichester.

LAWSON, B. (2000) How Designers Think (3rd Ed.), Architectural Press, Oxford.

LAWSON, B. (2004) What Designers Know, Architectural Press, Oxford.

LAWSON, B., DORST, K. (2009) Design Expertise, Architectural Press, Oxon.

PAHL, G., BEITZ, W. (1996) Engineering Design: A Systematic Approach (2. Ed.), Springer-Verlag London Limited, London.

ROMANIK, R. (2013) 12 best practices for retail-ready packaging, Packaging World, September 30, 2013. [http://www.packworld.com/packagedesign/retail-ready/12-best-practices-retail-ready-packaging] Access Date (24.10.2013).

ROOZENBURG, N.F.M., EEKELS, J. (1995) Product Design: Fundamental and Methods, John Wiley \& Sons, Chichester. 
Alındı: 05.09.2014; Son Metin: 09.03.2015

Anahtar Sözcükler: Beyin fırtınası; problem alanı; tasarım düşünce taktikleri; fikir geliştirme stratejileri; çözüm alanları.
WILTSCHNIG, S., CHRISTENSEN, B.T., BALL, L.J. (2013) Collaborative problem-solution co-evolution in creative design, Design Studies, 34(5) 515-42.

WRIGHT, I.C. (1998) Design Methods in Engineering and Product Design, McGraw-Hill Publishing Company, London.

\section{BIIR BEYIN FIRTINASI OTURUMUNDA TASARIM DÜŞÜNCE TAKTIKLERININ VE FIKIR GELIŞTIRME STRATEJILERININ KULLANIMI}

Proje yönergesinin dağıtılmasının ardından on üç tasarımcının katıldığı bir beyin fırtınası oturumu düzenlenmiş, oturumun sonucunda problem alanı irdelenerek ana tasarım fikri belirlenmiş ve çözüm alanları önerilmiştir. Oturumun belgeleri, tartışmalarda kullanılan tasarım düşünce taktikleri ve fikir geliştirme stratejilerinin saptanması için tematik olarak çözümlenmiştir. Çözümlemenin sonucunda, kişisel deneyimlerin kullanımı, problemin çözüm odaklı irdelemesi ve yönergenin teknik irdelemesi ana başlıkları altında toplanan on iki tasarım düşünce taktiğ belirlenmiştir. Ayrıca, karma çoklu paket, ambalaj tipi, içeriğin korunması, içeriğin görünürlüğü, sunum ve yeniden kullanım ana başlıkları altında toplanan on altı fikir geliştirme stratejisi belirlenmiştir. Taktikler çözüm odaklı tartışmaların üretilmesi için kullanılmış ve taktik kullanımının bir sonucu olarak, ana tasarım fikri olan karma çoklu paket, oturumun erken bir aşamasında önerilmiştir. Stratejiler ise tasarım fikirlerinin üretilmesinde kullanılmış ve proje hedeflerinin ortak olarak belirlenmesini sağlamıştır. Çözümleme sonucunda proje hedefleri pazarlama, sürdürülebilirlik ve ürün-kullanıcı etkileşimi olarak belirlenmiştir. Genel olarak değerlendirildiğinde, beyin fırtınası oturumunda yürütülen tartışmalar ana tasarım fikrinin proje hedefleri açılarından incelenmesini içermiş ve çeşitli çözüm alanlarının önerilmesi ile sonuçlanmıştır.

NAZ A.G.Z. BÖREKÇí; B.ID, MFA, PhD.

Received her BID from METU Department of Industrial Design in 1995, her MFA from Bilkent University IAED in 1997 and her PhD from University of Kent at Canterbury / KIAD in 2003. Currently is Assistant Professor at METU Department of Industrial Design. Academic research interests include design methods, collaboration with industry in industrial design education, and design for all. nborekci@metu.edu.tr 